\title{
Increasing Student Learning Motivation by Guidance and Counselling Teachers During the Covid-19 Pandemic
}

\author{
Mega Aria Monica, Nova Erlina, Novela Azalia
}

Universitas Islam Negeri Raden Intan Lampung

megaariamonica@radenintan.ac.id

Submitted : 2021-10-30, Revised : 2021-11-11, Accepted : 2021-11-27

\begin{abstract}
Motivation is an important thing in learning. During the current covid-19 pandemic, with many different learning patterns, it causes students to experience a decrease in learning motivation. The purpose of this study was to determine the role of guidance and counseling teachers in increasing student learning motivation during the covid-19 pandemic. This research uses a qualitative research type, with a case study research design. The results of the study show that the efforts of guidance and counseling teachers in increasing learning motivation are collaborating with subject teachers, homeroom teachers, and also information from parents of students.
\end{abstract}

Keywords: Covid-19 Pandemic; Guidance and Counseling Teacher Efforts; Learning Motivation

\section{Introduction}

At this time the world of education is facing a transition period, this is due to the COVID19 pandemic that is hitting several countries. One of the changes is the education system that is usually carried out, one of which is by implementing distance learning with an online system. The media that can be used by teachers in the online learning process such as Whatsapp, Zoom Meeting, Google Meet, Youtobe and various other social media (Atsani, 2020).

Changes in the learning system that occur greatly affect the learning motivation of students. With offline learning teachers are able to create a conducive classroom atmosphere to maintain students' learning motivation, but online learning makes it difficult for teachers to control a conducive learning atmosphere, this condition can cause students' learning motivation to decrease (Cahyani et al., 2020). This is in accordance with another opinion which states that students often experience learning saturation and this, if left unchecked, can affect their learning achievement (Fawaz et al., 2021).

Lack of motivation to learn can affect student learning outcomes. Motivation is a state or strength that comes from within a person and there is an impulse that leads to something to be achieved, where motivation will usually try to realize the behavior towards the goal in order to achieve a behavior that is directed towards the goal of achieving the goal of satisfaction (Osabiya, 2015). Learning motivation can affect student learning outcomes, the existence of motivation in learning is needed to foster student interest in a lesson, so students have the urge to carry out learning activities, sometimes students and educators do not pay attention to it, decreased motivation will have an impact to the learning outcomes of students themselves, therefore it is very important the role of BK teachers in an effort to increase students' learning motivation (Mushawir \& Nurul, 2015: 9).

A decrease in learning motivation can affect learning achievement. In line with this opinion, a decrease in learning achievement can arise from the performance of the school, one of which is an ineffective teacher in providing teaching to students, as a result students experience a lack of interest and attention, laziness and boredom in learning (Macklem, 2015). The characteristics of students who have good learning motivation, namely, the desire and desire to succeed, the encouragement and needs in learning, the ideals and hopes in the future, the appreciation in learning, the activities that attract attention in learning. , with a conducive learning environment, so that it allows students to learn well (Tharani et al., 2017).

Based on this, it is important that guidance and counseling teachers make efforts to improve the condition of students' learning motivation during the current covid-19 pandemic. The role of guidance and counseling teachers is very important in the world of education both 
in the continuity of the teaching and learning process. The changes that occur in the world of education today make teachers have to make innovations when providing learning and service delivery (Sitepu \& Nasution, 2017).

Guidance and counseling is a service that helps students both individually and in groups so that students can be independent and can develop optimally in many ways, be it in personal life, career planning and even learning abilities (Aqib Zainal, 2012:1). In giving attention to students who experience low learning motivation, guidance and counseling teachers strive, as follows: "...The efforts of guidance and counseling teachers: first, collaborate with several teachers, monitor assignments and absences, and provide appropriate services and also effective in this school, as well as providing an overview to students, what are the expectations of students, what are their aspirations, meaning that later students will make their own targets, make study schedules, such as a 24-hour time loop, in 24 hours it is only 1 hour to study, the child's own study schedule regulates, then we make achievement targets, for example how much the first semester will be worth, how to do it, so that the second semester increases ".

\section{Methods}

This type of research is descriptive qualitative research. This approach was chosen because it provides a more in-depth descriptive explanation about the role of counseling guidance teachers in increasing students' learning motivation during the COVID-19 pandemic. The population in this study were students of class VIII at MTSN 2 Tanggamus Lampung. Data collection techniques in this study used participant observation and structured interviews. Data analysis in this study is to use descriptive statistics to collect information about the findings obtained from interviews and observations.

\section{Results and Discussion}

Education is an important thing in human life. Every human being needs education to support the formation of generations who are knowledgeable, have character and are able to compete in future lives (Salsabila et al., 2020). During the current covid pandemic, it is related to the learning process in accordance with a circular from the government, the learning process is carried out online to cope with the increasingly widespread transmission of covid 19.

Based on this, the educational process during the current covid-19 pandemic will still run effectively even with online media. This is in accordance with what is stated in the National Education System Law article 13 paragraph 2 which states that formal and non-formal education carried out in the education system can be carried out face-to-face or remotely (Indonesia, 2003). Face-to-face learning can still run effectively using existing technology systems and there is feedback between teachers, students and parents (Latip, 2020). Other research states that the use of online learning can run effectively by using the preparations made by educators, namely preparing teaching materials that can attract the attention of students. (Wijoyo \& Nyanasuryanadi, 2020).

From the results of data and surveys related to learning motivation in 5 respondents, the following results were obtained:

1. Not enthusiastic about online learning

Not enthusiastic when participating in online learning. As for the behavior shown, such as, often do not collect assignments on time, do not wish to repeat learning outside of study hours. According to the respondents, this was due to the use of boring learning methods, such as the teacher not explaining the material and suddenly giving the task of taking notes in pages. 
2. Feeling bored in participating in online learning

Feeling bored and bored, often vented by playing games and preferring to leave the subject and help parents, and often not absent, not participating in online learning.

Based on the results of the survey, the lack of learning motivation of students can affect the low process of understanding learning which will affect student learning outcomes. In line with the results of the study, the giving of tasks and learning monotony resulted in the low process of understanding learning in students (Agusriani \& Fauziddin, 2021). Pendapat lain menyatakan bahwa kurang maksimalnya proses belajar dipengaruhi oleh rendahnya motivasi belajar yang dimiliki peserta didik (Nurrahmi, 2015).

Learning motivation is an impulse that moves individuals to achieve their goals in learning. Learning motivation is the tendency of students to carry out learning activities that are driven by the desire to achieve the best possible learning outcomes (Nurmala et al., 2014). Learning outcomes obtained by students without motivation will not be maximized. In line with this opinion, other research states that learning outcomes will be optimal if accompanied by high learning motivation in students (Andriani \& Rasto, 2019).

The emergence of learning motivation problems that occur to students during the online learning period during the current covid 19 pandemic is due to the lack of intensity of interaction between teachers and students such as regulations for teaching and learning activities during online learning, the time for completing assignments which tend to be short, so that can potentially reduce student learning outcomes (Oktawirawan, 2020). Factors that influence student learning motivation are low, namely learning facilities, interest factors, attention factors, self-ability factors, peer factors, and health factors (Rismawati et al., 2020). In line with this, the factors that influence learning motivation are: the ideals or aspirations of students, physical and spiritual conditions of students, environmental conditions of students, dynamic elements of learning, and teacher efforts to teach students (Moslem et al., 2019).

To overcome the problems of students' learning motivation during the COVID-19 pandemic, the role of guidance and counselling teachers is very important. This is in accordance with the opinion Setiadi et al., (2020) The tasks of guidance and counselling teachers that can be done in overcoming students' learning motivation are: 1) understanding the importance of learning and assignments to students in order to make changes in behaviour, 2) increasing students' willingness to carry out learning The role of the BK teacher is closely related to increasing learning motivation. students, 3) changing the pattern of the learning system, 4) applying learning methods, 5) organizing subject matter and how to face exams, 6) improving students' metacognition, and 7) developing learning styles. The success of the learning process during the current covid-19 pandemic greatly affects the role of guidance and counseling teachers in helping the smooth process of distance learning (Nugroho, 2020).

Based on the results of the study, it was found that the efforts made by guidance and counselling teachers in improving students' learning motivation problems at MTSN 2 Tanggamus Lampung, namely:

a. Guidance and counselling teachers collaborate with several teachers and parents

One of the efforts made by guidance and counselling teachers is to collaborate with subject teachers and homeroom teachers. motivation to learn or not. The form of collaboration between teachers and a number of related parties is needed, this aims to achieve the goals of the guidance and counselling program and for the success of students' studies in schools (Nugraha \& Rahman, 2017).

b. Monitoring Every Class Through Attendance

Then the effort that the guidance and counselling teacher does is to monitor each class through attendance because from the absence the guidance and counselling teacher can find out which students follow the online learning process and those who do not follow the learning process. Monitoring using attendance is an effective thing 
that guidance and counselling teachers can do in controlling the presence of students, with the presence of students it can be seen their learning motivation (Suhendra et al., 2016).

c. Monitoring Student Assignments

Furthermore, the guidance and counselling teacher's efforts are to monitor the tasks of the students. In this case, the guidance and counseling teacher cooperates with other subject teachers. Guidance and counseling teachers see which students submit assignments on time and who do not submit assignments on time, assuming that students who submit assignments on time still have good learning motivation. In line with this, students who can be categorized as having high learning motivation, namely, having an interest in doing the tasks/activities given, making effort or persistence to succeed, being diligent in doing assignments, having self-confidence during the activity process (Sudibyo et al., 2017).

d. Provide counseling services (Individual Counseling)

Based on the results of interviews conducted by researchers with guidance and counseling teachers, it was revealed that, during a pandemic like this, guidance and counseling teachers continue to carry out their obligations in carrying out their duties in providing services to students. Various efforts have been made to increase students' learning motivation, one of which is individual counseling services. This is reinforced by Prihatiningtia (2020) opinion which states that one of the counselling that can be done to increase learning motivation is individual counselling. The following are the stages of the individual counselling process carried out by guidance and counselling teachers:

1) Early stage

The initial stages carried out by the two guidance and counselling teachers were as follows: "greeting students by answering students' greetings, asking students how they are, talking about students and students' families, guidance and counselling teachers conveying the intent and purpose of holding counselling sessions" (Suryadi, 2019).

\section{2) Work Stage Or Mid}

The middle stages carried out by the two guidance and counselling teachers are: "guidance and counselling teachers convey the problems of students regarding the low motivation to learn. the opportunity to reveal what really happened, the guidance and counselling teacher conducted a question and answer session with students related to learning motivation, then the guidance and counselling teacher recorded what the progress of the students was.

3) Final Stage

The final stage is carried out by the two guidance and counselling teachers as follows: "guidance and counselling teachers help direct student change decision alternatives, guidance and counselling teachers assist students in planning decisions, guidance and counselling teachers and students conclude activities together. what has been done, students and guidance and counselling teachers talk about the next meeting, if it is felt that it is not completed, ending the counselling session. 


\section{Conclusions and Suggestions}

Based on the description above, it can be concluded that many students experience low learning motivation, therefore guidance and counselling teachers need to make appropriate efforts in increasing students' learning motivation. As for the efforts that have been made at MTSN 1 Tanggamus Lampung, namely, guidance and counselling teachers have collaborated with several subject teachers, homeroom teachers, parents of students and carry out individual counselling services. Suggestions for further research is the need for further research related to techniques in guidance and counselling that can be used to overcome the problems of students' learning motivation.

\section{References}

Agusriani, A., \& Fauziddin, M. (2021). Strategi orangtua mengatasi kejenuhan anak belajar dari rumah selama pandemi COVID-19. Jurnal Obsesi: Jurnal Pendidikan Anak Usia Dini, 5(2), 1729-1740.

Andriani, R., \& Rasto, R. (2019). Motivasi belajar sebagai determinan hasil belajar siswa. Jurnal Pendidikan Manajemen Perkantoran (JPManper), 4(1), 80-86.

Atsani, K. H. L. G. M. Z. (2020). Transformasi media pembelajaran pada masa Pandemi COVID-19. Al-Hikmah: Jurnal Studi Islam, 1(1), 82-93.

Cahyani, A., Listiana, I. D., \& Larasati, S. P. D. (2020). Motivasi Belajar Siswa SMA pada Pembelajaran Daring di Masa Pandemi Covid-19. IQ (Ilmu Al-Qur'an): Jurnal Pendidikan Islam, 3(01), 123-140.

Fawaz, M., Al Nakhal, M., \& Itani, M. (2021). COVID-19 quarantine stressors and management among Lebanese students: a qualitative study. Current Psychology, 1-8.

Indonesia, P. R. (2003). Undang-undang Republik Indonesia nomor 20 tahun 2003 tentang sistem pendidikan nasional. Departemen Pendidikan Nasional.

Latip, A. (2020). Peran literasi teknologi informasi dan komunikasi pada pembelajaran jarak jauh di masa pandemi Covid-19. EduTeach: Jurnal Edukasi Dan Teknologi Pembelajaran, 1(2), 108-116.

Macklem, G. L. (2015). Boredom in the classroom: Addressing student motivation, selfregulation, and engagement in learning (Vol. 1). Springer.

Moslem, M. C., Komaro, M., \& Yayat, Y. (2019). Faktor-Faktor yang Menyebabkan Rendahnya Motivasi Belajar Siswa dalam Mata Pelajaran Aircraft Drawing di SMK. Journal of Mechanical Engineering Education, 6(2), 258-265.

Mushawir, \& Nurul. (2015). Hubungan Gaya Belajar dan Motivasi Belajar Dengan Hasil Belajar Biologi Siswa Kelas XI IPA SMA Negeri 1 tenate Rilau. Jurnal Bionature, 16(1).

Nugraha, A., \& Rahman, F. A. (2017). Strategi kolaborasi orangtua dengan konselor dalam mengembangkan sukses studi siswa. Jurnal Konseling GUSJIGANG, 3(1).

Nugroho, G. B. (2020). Peran Guru Bimbingan Dan Konseling Dalam Pendampingan Belajar Siswa Selama Pembelajaran Online. Psiko Edukasi, 18(1), 73-83.

Nurmala, D. A., Tripalupi, L. E., \& Suharsono, N. (2014). Pengaruh motivasi belajar dan aktivitas belajar terhadap hasil belajar akuntansi. Jurnal Pendidikan Ekonomi Undiksha, $4(1)$.

Nurrahmi, H. (2015). Kompetensi profesional guru bimbingan dan konseling. Jurnal Dakwah 
Alhikmah, 9(1), 45-55.

Oktawirawan, D. H. (2020). Faktor pemicu kecemasan siswa dalam melakukan pembelajaran daring di masa pandemi covid-19. Jurnal Ilmiah Universitas Batanghari Jambi, 20(2), $541-544$.

Osabiya, B. J. (2015). The effect of employees motivation on organizational performance. Journal of Public Administration and Policy Research, 7(4), 62-75.

Prihatiningtia, P. (2020). Pengaruh Layanan Konseling Individu dengan Teknik Modelling untuk Meningkatkan Motivasi Belajar di SMA Negeri 1 Tambakboyo. Nusantara of Research: Jurnal Hasil-Hasil Penelitian Universitas Nusantara PGRI Kediri, 7(1), 4956.

Rismawati, M., Khairiati, E., \& Khatulistiwa, S. P. (2020). nalisis Faktor Yang Mempengaruhi Rendahnya Motivasi Belajar Siswa Pada Mata Pelajaran Matematika. J-PiMat: Jurnal Pendidikan Matematika, 2(2), 203-212.

Salsabila, U. H., Sari, L. I., Lathif, K. H., Lestari, A. P., \& Ayuning, A. (2020). Peran Teknologi Dalam Pembelajaran Di Masa Pandemi Covid-19. Al-Mutharahah: Jurnal Penelitian Dan Kajian Sosial Keagamaan, 17(2), 188-198.

Setiadi, G., Sholihun, M., \& Yuwita, N. (2020). Peranan Guru Bimbingan Konseling Dalam Memotivasi Peserta Didik Selama Masa Pandemi Covid-19 di SMA Darut Taqwa Pasuruan. Al-Isyrof: Jurnal Bimbingan Konseling Islam, 2(2), 89-107.

Sitepu, J. M., \& Nasution, M. (2017). Pengaruh Konsep Diri terhadap Coping Stress pada Mahasiswa FAI UMSU. Intiqad: Jurnal Agama Dan Pendidikan Islam, 9(1), 68-83.

Sudibyo, E., Jatmiko, B., \& Widodo, W. (2017). Pengembangan instrumen motivasi belajar fisika: angket. Jurnal Penelitian Pendidikan IPA, 1(1), 13-21.

Suhendra, M., Neviyarni, S., \& Ahmad, R. (2016). Kontribusi Motivasi Berprestasi terhadap Regulasi Diri siswa Membolos di Madrasah Aliyah Negeri 2 Payakumbuh serta Implikasinya terhadap Layanan Bimbingan dan Konseling. Konselor, 5(2), 124-132.

Suryadi, S. (2019). Konseling Individual Untuk Mengatasi Perilaku Bullying Pada Perbedaan Gender di MTs Negeri Sleman Maguwoharjo Yogyakarta. Jurnal Bimbingan Dan Konseling Islam, 9(1), 54-67.

Tharani, A., Husain, Y., \& Warwick, I. (2017). Learning environment and emotional wellbeing: A qualitative study of undergraduate nursing students. Nurse Education Today, 59, 82-87.

Wijoyo, H., \& Nyanasuryanadi, P. (2020). Analisis Efektifitas Penerapan Kurikulum Pendidikan Sekolah Minggu Buddha Di Masa Pandemi COVID-19. JP3M: Jurnal Pendidikan, Pembelajaran Dan Pemberdayaan Masyarakat, 2(2), 166-174.

Zainal, A. (2012). Ikhtisar Bimbingan dan Konseling. Yrma Widya. 